\title{
Implementasi Empirical Best Linear Unbiased Prediction Fay-Herriot dalam Menduga Rata-Rata Pengeluaran per Kapita Level Kecamatan di Provinsi Jawa Timur dengan Tambahan Informasi Cluster
}

\author{
(Implementation Empirical Best Linear Unbiased Prediction Fay-Herriot for Average per Capita \\ Expenditure at Sub-District Level in Jawa Timur Province with Additional Cluster Information)
}

\author{
Mochamad Wildan Maulana ${ }^{1 *}$, Ika Yuni Wulansari² \\ ${ }^{1,2}$ Politeknik Statistika STIS \\ Jl. Otto Iskandardinata No.64C Jakarta 13330 \\ E-mail: 211709834@stis.ac.id
}

\begin{abstract}
ABSTRAK
Salah satu indikator ekonomi yang dapat mengukur tingkat kesejahteraan adalah kemiskinan. Penduduk tergolong miskin apabila rata-rata pengeluaran per kapita setiap bulannya dibawah garis kemiskinan. Provinsi Jawa Timur terpilih sebagai lokus penelitian dikarenakan memiliki jumlah penduduk miskin tertinggi di Indonesia selama satu dekade terakhir. Data yang digunakan berasal dari Susenas Maret 2019 dan Podes 2018 dengan 666 observasi level kecamatan. Upaya pengentasan kemiskinan memerlukan data yang akurat dan menjangkau hingga wilayah terkecil. Akan tetapi tidak semua wilayah memiliki sampel yang cukup atau bahkan tidak memiliki sampel sama sekali. Hal ini tidak memungkinkan untuk melakukan estimasi langsung. Oleh karena itu dibutuhkan metode statistik untuk dapat mengestimasi area kecil dengan baik. Metode yang dapat digunakan untuk menduga area kecil adalah Small Area Estimation (SAE). Penelitian ini menggunakan metode SAE dengan Model Empirical Best Linear Unbiased Prediction Fay-Herriot. Hasil yang diperoleh bahwa metode SAE dapat memberikan pendugaan yang lebih baik dibanding estimasi langsung yang ditunjukan dengan nilai Relative Root Mean Square Error (RRMSE) lebih kecil dibanding estimasi langsung. Estimasi pada non-sample area dilakukan dengan memanfaatkan informasi cluster.
\end{abstract}

Kata Kunci: Rata-Rata Pengeluaran per Kapita, SAE, EBLUP FH, RRMSE, Non-Sample Area

\section{ABSTRACT}

One of the economic indicators that can measure the level of welfare is poverty. The population is classified as inferior if the average monthly per capita expenditure is below the poverty line. East Java province was chosen as the research locus because it has the highest number of poor people in Indonesia over the past decade. The data used comes from the March 2019 Susenas and 2018 Podes with 666 sub-district level observations. Poverty alleviation efforts require data that is accurate and reaches down to the smallest areas. However, not all regions have sufficient samples or even no samples at all. It is not possible to make direct estimates. Therefore, statistical methods are needed to be able to estimate small areas reasonably. The technique that can be used to estimate a small area is Small Area Estimation (SAE). This study use SAE methods with Empirical Best Linear Unbiased Prediction Fay-Herriot models The results obtained are that SAE methods can provide better estimates than direct estimates, which are indicated by Relative Root Mean Square Error (RRMSE) values that are smaller than direct estimates. Estimation for non-sample area can be used by utilizing cluster information.

Keywords: Average per Capita Expenditure, SAE, EBLUP FH, RRMSE, Non-Sample Area

\section{PENDAHULUAN}

World Bank (2000) mendefinisikan kemiskinan sebagai kehilangan kesejahteraan (deprivation of wellbeing) dengan kata lain semakin banyak penduduk miskin yang tinggal di suatu daerah, maka daerah tersebut dapat dikatakan kurang sejahtera. Badan Pusat Statistik mengukur kemiskinan menggunakan konsep kemampuan memenuhi kebutuhan dasar (basic need approach) yang dilihat dari sisi pengeluaran ekonomi dalam memenuhi kebutuhan dasar makanan dan bukan makanan. Ukuran tersebut adalah rata-rata pengeluaran per kapita dengan definisi biaya yang dikeluarkan untuk konsumsi seluruh anggota rumah tangga selama sebulan dibagi dengan banyaknya anggota rumah tangga.

Selama sepuluh tahun terakhir, rata-rata pengeluaran per kapita di Indonesia terus mengalami peningkatan. Seperti tahun 2019, terjadi peningkatan rata-rata pengeluaran per kapita sebesar 3,6 persen dari tahun sebelumnya (BPS, 2019). Hal ini berarti biaya yang dikeluarkan untuk konsumsi setiap anggota rumah tangga selama sebulan baik dari makanan maupun non makanan mengalami peningkatan. Berita Resmi Statistik (BRS) yang dikeluarkan oleh BPS juga menjelaskan bahwa kemiskinan di Indonesia terus membaik 
di setiap tahunnya. Perbaikan ini ditandai dengan turunnya persentase penduduk miskin dari waktu ke waktu. Penduduk tergolong miskin apabila rata-rata pengeluaran per kapita sebulan di bawah garis kemiskinan. Pada maret 2019, jumlah penduduk miskin di Indonesia sebanyak 25,14 juta orang. Dibandingkan dengan tahun sebelumnya, jumlah penduduk miskin turun sebesar 0,25 persen terhadap September 2018 dan 0,41 persen terhadap Maret 2018. Namun, upaya perbaikan pemerintah belum sepenuhnya berhasil. Hal ini dikarenakan jumlah penduduk miskin di beberapa daerah masih tergolong tinggi. BPS (2019) menyatakan bahwa sumbangan penduduk miskin terbesar berada di Provinsi Jawa Timur dengan total 4112,25 ribu penduduk miskin. Selama satu dekade terakhir, Provinsi Jawa Timur menjadi provinsi dengan jumlah penduduk miskin tertinggi di Indonesia.

Upaya pengentasan kemiskinan harus terus dilakukan oleh pemerintah pusat maupun daerah seperti yang tertuang dalam kesepakatan 17 program pembangunan berkelanjutan atau Suistanable Development Goals (SDGs) dimana fokus pilar pertama yaitu tanpa kemiskinan (No Poverty). Pada pilar tersebut berisi target mengentaskan kemiskinan salah satunya yaitu pada tahun 2030 setengah proporsi laki-laki, perempuan dan anak-anak dari semua usia yang hidup didalam kemiskinan disemua dimensi dikurangi (Bappenas, 2019). Kemudian, target pengurangan kemiskinan oleh pemerintah, yang tertuang dalam Rencana Pembangunan Jangka Menengah Nasional (RPJMN), sebesar 6-8 persen dalam jangka waktu lima tahun sehingga perlu adanya koordinasi baik pemerintah pusat maupun daerah untuk mengentaskan kemiskinan.

Berdasarkan UU Nomor 16 Tahun 1997, peranan BPS adalah menjadi penyedia data bagi pemerintah dan masyarakat berupa data sekunder hasil sensus dan survei yang dilakukannya. Survei yang dilakukan oleh BPS dalam mengumpulkan data rata-rata pengeluaran per kapita adalah Survei Sosial Ekonomi Nasional (Susenas) (Kusuma, 2017). Susenas dilaksanakan dua kali dalam satu tahun yaitu pada bulan Maret untuk mengestimasi level kabupaten/kota dan bulan September untuk mengestimasi level provinsi. Survei ini menyediakan data dari berbagai aspek sosial ekonomi dan pemenuhan kebutuhan hidup sandang, pangan, papan, pendidikan, kesehatan, keamanan, dan kesempatan kerja (BPS, 2019). Namun, kecukupan sampel Susenas ditingkat kecamatan menyebabkan tidak dapat dilakukannya estimasi secara langsung. Sedangkan, proses perencanaan pembangunan wilayah dibutuhkan data sampai wilayah tersebut. Keterbatasan ini memerlukan metode yang dapat mengestimasi wilayah kecil dengan memanfaatkan data yang telah tersedia. Salah satu metodenya yaitu Small Area Estimation (SAE).

Rao (2003) menyatakan bahwa SAE merupakan sebuah metode estimasi tidak langsung (indirect estimation) dengan memanfaatkan informasi area sekitar untuk memperoleh informasi area yang lebih kecil. Informasi area sekitar diperoleh dari variabel penyerta (auxiliary variable) yang didapatkan dari estimasi langsung (direct estimation). Variabel penyerta yang digunakan seharusnya tidak memiliki error untuk meminimalisir Mean Square Error (MSE) yang besar. Variabel ini bisa didapatkan melalui pendataan sensus seperti Potensi Desa (Podes).

Penelitian yang berkaitan dengan Small Area Estimation (SAE) telah banyak dilakukan di Indonesia. Sebagian besar peneliti menggunakan data yang berasal dari BPS sebagai penyedia data resmi pemerintah. Seperti yang dilakukan oleh Amaliana dan Lusiana (2017) menggunakan data pengeluaran per kapita yang berasal dari BPS. Metode yang dipakai adalah EBLUP dengan amatan Provinsi Jawa Timur khususnya Kabupaten Jember tahun 2008. Penelitian ini mengambil data pengeluaran rumah tangga per kapita selama sebulan yang berasal dari Susenas 2008 dan beberapa variabel penyerta yang berasal dari Podes 2008 seperti jumlah keluarga yang tinggal di pemukiman kumuh, jumlah keluarga pengguna listrik PLN, jumlah keluarga yang mengenyam pendidikan (SD, SMP, SMA, dan Perguruan Tinggi) dan sebagainya. Hasil yang didapatkan bahwa estimasi tidak langsung menggunakan metode EBLUP menghasilkan nilai MSE yang lebih kecil dibanding estimasi langsung. Sehingga penggunaan SAE jauh lebih baik dibanding estimasi langsung untuk menduga pengeluaran rumah tangga per kapita selama sebulan di Kabupaten Jember. Dengan demikian, penelitian ini akan mengestimasi rata-rata pengeluaran per kapita di Jawa Timur menggunakan Small Area Estimation dengan metode Empirical Best Linear Unbiased Prediction Fay-Herriot. Selain itu dalam estimasi langsung menggunakan survei memungkinan adanya kecamatan yang tidak terambil sampel, maka akan diterapkan juga tambahan informasi cluster untuk mengestimasi wilayah non-sample.

\section{METODE}

\section{Metode Analisis}

\section{Small Area Estimation}

Rao (2003) menjelaskan bahwa SAE terbagi menjadi dua model dasar antara lain model dasar tingkat area (basic area level model) dimana model ini digunakan ketika variabel penyertanya tersedia hingga level 
area dan model dasar tingkat unit (basic unit level model) yang digunakan ketika variabel penyertanya tersedia hingga level unit.

a. Model Dasar Tingkat Area

Model dasar tingkat area didasarkan pada ketersediaan variabel penyerta yang hanya tersedia pada level area tertentu. Parameter yang diestimasi adalah $\theta_{i}$, dengan model linear sebagai berikut :

$$
\theta_{i}=\boldsymbol{x}_{i}^{T} \boldsymbol{\beta}+z_{i} v_{i}
$$

Keterangan:

$\beta=\left(\beta_{0}, \ldots, \beta_{p}\right)^{T}$ adalah vektor koefisien regresi berukuran $(p+1) \times 1$

$z_{i}=$ Konstanta positif yang diketahui $(i=1,2, \ldots, n)$

$v_{i}=$ Random effect dari small area, diasumsikan $v_{i} \sim$ iid $N\left(0, \sigma_{v}^{2}\right)$

$n=$ Jumlah observasi

Persamaan (1) memiliki asumsi bahwa nilai pendugaan langsung $\hat{\theta}_{i}$ diketahui dan dapat ditulis sebagai berikut:

$$
\hat{\theta}_{i}=\theta_{i}+e_{i}
$$

dimana $e_{i}$ adalah sampling error yang diasumsikan $\mathrm{e}_{\mathrm{i}} \sim \mathrm{N}\left(0, \psi_{i}\right)$ dengan $i=1,2, \ldots, n$.

Model dasar tingkat area memiliki dua tingkat komponen model diantaranya komponen model estimasi tidak langsung yaitu pada persamaan (1) dan komponen model estimasi langsung sesuai dengan persamaan (2). Gabungan dari kedua model dapat ditulis sebagai berikut:

$$
\widehat{\theta_{l}}=\boldsymbol{x}_{\boldsymbol{i}}^{\boldsymbol{T}} \boldsymbol{\beta}+z_{i} v_{i}+e_{i}
$$

dengan $i=1,2, \ldots, n$.

b. Model Dasar Tingkat Unit

Model dasar tingkat unit merupakan model dengan data pendukung yang tersedia bersesuaian secara individu dengan variabel yang ingin diteliti. Data tersebut merupakan informasi yang tersedia pada level unit sampel. Parameter yang diestimasi adalah $\theta_{i j}$, dengan model linear sebagai berikut:

$$
\theta_{i j}=\boldsymbol{x}_{\boldsymbol{i} \boldsymbol{T}}^{\boldsymbol{T}} \boldsymbol{\beta}+u_{i j}+e_{i}
$$

dimana $j=1,2, \ldots, m$ dan $i=1,2, \ldots, n$ serta $e_{i}$ diasumsikan berdistribusi normal.

Penelitian ini menggunakan model dasar tingkat area dimana variabel penyertanya tersedia level kecamatan.

\section{Empirical Best Linear Unbiased Prediction Fay-Herriot (EBLUP FH)}

Model Empirical Best Linear Unbiased Prediction Fay-Herriot (EBLUP FH) didasarkan pada metode estimasi General Linear Mixed Model (GLMM) yang ditulis sebagai berikut:

$$
\theta_{i}=\boldsymbol{x}_{\boldsymbol{i}}^{\boldsymbol{T}} \boldsymbol{\beta}+z_{i} v_{i}+e_{i}
$$

dimana $i=1,2, \ldots, n$ dan $v_{i} \sim \operatorname{iidN}\left(0, \sigma_{v}^{2}\right)$ serta $e_{i} \sim N\left(0, \psi_{i}\right)$ dengan keragaman $\psi_{i}$ diketahui. Asumsi untuk $v_{i}$ dan $e_{i}$ saling independen, dimana $\mathrm{n}$ adalah banyaknya area. Apabila nilai $\sigma_{v}^{2}$ diketahui, maka estimator menjadi Best Linear Unbiased Predictor (BLUP) dengan formula sebagai berikut:

$$
\hat{\theta}_{i}^{B L U P}=\boldsymbol{x}_{\boldsymbol{i}}^{\boldsymbol{T}} \widetilde{\boldsymbol{\beta}}+\gamma_{i}\left(\hat{\theta}_{i}-\boldsymbol{x}_{\boldsymbol{i}}^{\boldsymbol{T}} \widetilde{\boldsymbol{\beta}}\right)
$$

dimana $\hat{\theta}_{i}$ hasil estimasi langsung dari area ke-i $(i=1,2, \ldots, n)$, n jumlah observasi, $\gamma_{i}$ adalah $\frac{\sigma_{v}^{2}}{\psi_{i}+\sigma_{v}^{2}}, \sigma_{v}^{2}$ varians dari random effect area, $\psi_{i}$ adalah $\operatorname{MSE}\left(\hat{\theta}_{i}\right), \boldsymbol{x}_{\boldsymbol{i}}^{\boldsymbol{T}}$ vektor variabel penyerta serta nilai $\widetilde{\boldsymbol{\beta}}=$ $\left[\sum_{i=1}^{n} \frac{x_{i} x_{i}^{T}}{\left(\psi_{i}+\sigma_{v}^{2}\right)}\right]^{-1}\left[\sum_{i=1}^{n} \frac{x_{i} \widehat{\theta}_{i}}{\left(\psi_{i}+\sigma_{v}^{2}\right)}\right]$.

Penduga BLUP diatas masih mengandung nilai $\sigma_{v}^{2}$ karena metode BLUP diasumsikan bahwa $\sigma_{v}^{2}$ diketahui, padahal dalam praktiknya varians dari random effect $\left(\sigma_{v}^{2}\right)$ tidak diketahui. Sehingga nilai $\left(\sigma_{v}^{2}\right)$ harus diestimasi. Metode yang dapat digunakan untuk mengestimasi varian dari random effect adalah Maximum Likelihood (ML) atau Restricted Maximum Likelihood (REML). Pendugaan terhadap $\sigma_{v}^{2}$, akan diperoleh Penduga EBLUP dapat ditulis dalam formula sebagai berikut

$$
\hat{\theta}_{i}^{\mathrm{EBLUP}}=\boldsymbol{x}_{\boldsymbol{i}}^{\boldsymbol{T}} \widehat{\boldsymbol{\beta}}+\widehat{\gamma}_{l}\left(\widehat{\theta}_{l}-\boldsymbol{x}_{\boldsymbol{i}}^{\boldsymbol{T}} \widehat{\boldsymbol{\beta}}\right) \text {. }
$$

dengan nilai $\widehat{\boldsymbol{\beta}}$ adalah

$$
\widehat{\boldsymbol{\beta}}=\widehat{\boldsymbol{\beta}}\left(\sigma_{v}^{2}\right)=\left[\sum_{i=1}^{n} \frac{x_{i} x_{i}^{T}}{\left(\psi_{i}+\widehat{\sigma}_{v}^{2}\right)}\right]^{-1}\left[\sum_{i=1}^{n} \frac{x_{i} \widehat{\theta}_{i}}{\left(\psi_{i}+\widehat{\sigma}_{v}^{2}\right)}\right] .
$$

Melalui proses yang telah dilakukan, didapatkan bahwa $\hat{\theta}_{i}$ merupakan penduga suatu wilayah yang takbias, linear, serta bersifat homoskedastis. Selanjutnya, evaluasi model dapat menggunakan Relative Root Mean Square Error (RRMSE). Perhitungan nilai RRMSE dapat diperoleh dari formula berikut:

Mean Square Error (MSE) dan Relative Root Mean Square Error (RRMSE) 
Baik tidaknya estimasi tidak langsung dapat diukur dari nilai Mean Square Error (MSE). Pada model EBLUP FH, MSE dapat dirumuskan sebagai berikut:

dimana:

$$
\operatorname{MSE}\left(\hat{\theta}_{i}^{E B L U P}\right)=g_{1 i}\left(\hat{\sigma}_{v}^{2}\right)+g_{2 i}\left(\hat{\sigma}_{v}^{2}\right)+2 g_{3 i}\left(\hat{\sigma}_{v}^{2}\right)
$$

$g_{1 i}\left(\hat{\sigma}_{v}^{2}\right)=\frac{\widehat{\sigma}_{v}^{2} \psi_{i}}{\psi_{i}+\widehat{\sigma}_{v}^{2}}=\hat{\gamma}_{i} \psi_{i}$

$g_{2 i}\left(\hat{\sigma}_{v}^{2}\right)=\left(1-\hat{\gamma}_{i}\right)^{2} \boldsymbol{x}_{\boldsymbol{i}}^{\boldsymbol{T}}\left[\sum_{i=1}^{n} \frac{\boldsymbol{x}_{\boldsymbol{i}} \boldsymbol{x}_{\boldsymbol{i}}^{\boldsymbol{T}}}{\left(\psi_{i}+\hat{\sigma}_{v}^{2}\right)}\right]^{-1} x_{i}$

$g_{3 i}\left(\hat{\sigma}_{v}^{2}\right)=\psi_{i}^{2}\left(\psi_{i}+\hat{\sigma}_{v}^{2}\right)^{-3} \bar{V}\left(\hat{\sigma}_{v}^{2}\right)$

$\bar{V}\left(\hat{\sigma}_{v}^{2}\right)$ merupakan ragam asimptot dari $\left(\hat{\sigma}_{v}^{2}\right)$ dengan rumus

$\bar{V}\left(\hat{\sigma}_{v}^{2}\right)=2\left[\sum_{i=1}^{n}\left(\hat{\sigma}_{v}^{2}+\psi_{i}\right)^{-2}\right]^{-1}$

Selanjutnya dapat menggunakan Relative Root Mean Square Error (RRMSE) untuk mengevaluasi hasil estimasi. Perhitungan nilai RRMSE dapat diperoleh dari formula berikut:

$$
\operatorname{RRMSE}\left(\hat{\theta}_{i}\right)=\frac{\sqrt{M S E\left(\widehat{\theta}_{i}\right)}}{\widehat{\theta}_{i}} \times 100 \%
$$

\section{EBLUP FH dengan Informasi Cluster}

Penelitian yang dilakukan oleh Annisa (2014) dengan memodifikasi pada persamaan EBLUP untuk daerah yang tidak tersampel dengan memasukan informasi cluster kedalam persamaan $\hat{\theta}_{i}^{E B L U P}=\boldsymbol{x}_{\boldsymbol{i}}^{\boldsymbol{T}} \widetilde{\boldsymbol{\beta}}$ yang bertjuan untuk menghasilkan estimasi pada daerah yang tidak tersampel menjadi lebih baik. Haris (2019) mengembangkan fungsi SAE clustering untuk mengestimasi wilayah non sample. Pada prosesnya, clustering didasarkan pada variabel penyerta $X$ yang dilakukan di seluruh wilayah penelitian baik yang tersampel maupun tidak tersampel. Selanjutnya akan diperoleh seluruh wilayah penelitian masuk kedalam cluster tertentu. Hal ini dapat digunakan untuk memperbaiki pendugaan daerah yang tidak tersampel. Informasi cluster diperoleh dengan memasukan pengaruh acak area pada persamaan EBLUP. Pengaruh acak area akan dicari pada masingmasing cluster yang berfungsi untuk memperoleh nilai pengaruh acak area pada daerah tertentu. Pengaruh acak area yang diperoleh selanjutnya dirata-rata, hasil dari rata-rata tersebut dimasukan kedalam model sebagai penduga pengaruh acak area untuk daerah yang tidak tersampel. Berikut merupakan formula penambahan ratarata pengaruh acak area:

$$
\overline{\hat{v}}_{k}=\frac{1}{n_{k}} \sum_{i=1}^{n_{k}} \hat{v}_{i}
$$

dimana $\overline{\hat{v}}_{k}$ merupakan rata-rata pengaruh acak area pada cluster ke-k, $n_{k}$ adalah banyaknya area sampel pada cluster ke-k, dan $\hat{v}_{i}$ adalah Pengaruh acak area sampel ke-i. Persamaan (11) selanjutnya disubtitusi kedalam persamaan EBLUP $\hat{\theta}_{i}^{E B L U P}=\boldsymbol{x}_{\boldsymbol{i}}^{\boldsymbol{T}} \boldsymbol{\beta}$ maka akan diperoleh persamaan estimasi menggunakan metode EBLUP dengan informasi cluster. Berikut formula yang terbentuk:

$$
\hat{\theta}_{i}^{E B L U P C L}=\boldsymbol{x}_{\boldsymbol{i}}^{\boldsymbol{T}} \widehat{\boldsymbol{\beta}}+\overline{\hat{v}}_{k}
$$

dengan $\boldsymbol{x}_{\boldsymbol{i}}^{\boldsymbol{T}}$ adalah matriks dari variabel penyerta, $\boldsymbol{\beta}$ adalah vektor koefisien regresi berukuran $(p+1) \times 1$, $\overline{\hat{v}}_{k}$ rata-rata pengaruh acak area pada cluster ke-k. Adapun nilai Mean Square Error (MSE) dan Relative Root Mean Square Error (RRMSE) pada EBLUP FH non-sample area memiliki formula yang sama seperti pencarian MSE pada Model EBLUP FH yaitu persamaan (9).

\section{Rata-Rata Pengeluaran per Kapita}

Pengeluaran rumah tangga sebulan merupakan semua biaya yang dikeluarkan rumah tangga dalam kurun waktu sebulan untuk memenuhi kebutuhan konsumsi seluruh anggota rumah tangga. Sedangkan rata-rata pengeluaran per kapita sebulan merupakan besarnya pengeluaran setiap anggota rumah tangga dalam kurun waktu satu bulan. Data rata-rata pengeluaran per kapita diperoleh dari pembagian antara pengeluaran rumah tangga sebulan dengan jumlah anggota rumah tangga (BPS, 2008). Semakin besar pengeluaran seseorang, menunjukan besarnya pendapatan yang diperoleh. Dalam hal ini, pendapatan seseorang akan berbanding lurus dengan pengeluarannya. Formula rata-rata pengeluaran per kapita $\left(\theta_{i}\right)$ dapat ditulis sebagai berikut:

$$
\hat{\theta}_{i}=\frac{\text { Jumlah Pengeluaran per Kapita di Kecamatan } k e-i}{\text { Jumlah Sampel Rumah Tangga di Kecamatan } k e-i} .
$$

Estimator yang dihitung pada penelitian ini adalah rata-rata pengeluaran per kapita per kecamatan yang tertulis pada persamaan (13). Sedangkan nilai Mean Square Error (MSE) diperoleh menggunakan formula sebagai berikut: 


$$
\operatorname{MSE}\left(\hat{\theta}_{i}\right)=\operatorname{Var}\left(\hat{\theta}_{i}\right)+\operatorname{Bias}^{2}\left(\hat{\theta}_{i}\right)
$$

\section{Metode Pengumpulan Data}

Data yang digunakan dalam penelitian ini adalah data sekunder Susenas Maret 2019 berupa direct estimation rata-rata pangeluaran per kapita yang diperoleh dari Badan Pusat Statistik (BPS). Wilayah yang dijadikan lokus penelitian adalah seluruh kecamatan di Provinsi Jawa Timur dengan jumlah kecamatan sebanyak 666 kecamatan. Variabel pendukung diperoleh dari Podes 2018 dengan rincian sebagai berikut:

1. Jumlah Keluarga Pengguna PLN (P_PLN),

2. Jumlah Apotek (P_APOTEK),

3. Jumlah Posyandu dengan Kegiatan/pelayanan Setiap Sebulan Sekali (P_POSYANDU),

4. Jumlah Warga yang Menjadi Peserta BPJS Kesehatan Penerima Bantuan Iuran PBI dan Jamkesda Selama Tahun 2017 (P_BPJS),

5. Jumlah Surat Miskin/SKTM yang Dikeluarkan Desa/kelurahan Selama Tahun 2017 (P_SKM),

6. Jumlah Menara Base Tranceiver Station (P_BTS),

7. Jumlah KUD yang Beroperasi di Desa/kelurahan (P_KUD),

8. Jumlah Koperasi Simpan Pinjam (Kospin) yang Masih Aktif/beroperasi (P_KOPERASI),

9. Jumlah Kredit Usaha Rakyat yang Diterima Warga Desa/kelurahan Selama Setahun Terakhir (P_KUR),

10. Jumlah Jenjang Pendidikan Sekolah Dasar (SD) Negeri dan Swasta (P_SD),

11. Jumlah Jenjang Pendidikan Sekolah Menengah Pertama (SMP) Negeri dan Swasta (P_SMP),

12. Jumlah Jenjang Pendidikan Sekolah Menengah Keatas dan Sekolah Menengah Kejuruan (SMA dan SMK) Negeri dan Swasta (P_SMA),

13. Jumlah Jenjang Pendidikan Akademi/Perguruan Tinggi Negeri dan Swasta (P_PT),

14. Jumlah Fasilitas Kesehatan yakni Rumah Sakit, Puskesmas dan Rumah Bersalin (P_FASKES),

15. Jumlah Tenaga Kesehatan yakni Praktik Dokter dan Praktik Bidan (P_NAKES).

\section{HASIL DAN PEMBAHASAN}

\section{Permodelan Rata-Rata Pengeluaran per Kapita dengan Small Area Estimation}

\section{Pemilihan Variabel Penyerta}

Sebelum dilakukan pembangunan model small area estimation (SAE), diperlukan pemilihan variabel penyerta. Variabel penyerta yang baik ketika variabel tersebut memiliki korelasi dengan variabel respon dalam hal ini rata-rata pengeluaran per kapita hasil dari estimasi langsung. Pemilihan variabel penyerta melalui signifikansi korelasi masing-masing variabel terhadap variabel yang akan diestimasi. Sebanyak 15 variabel disediakan untuk menjadi kandidat variabel penyerta, variabel tersebut dipilih berdasarkan literature review dari penelitian terdahulu. Berdasarkan kandidat variabel penyerta yang disediakan, 13 variabel dapat dinyatakan berkorelasi dengan variabel respon yang ditampilkan melalui Tabel 1.

Tabel 1. Korelasi variabel penyerta dengan hasil estimasi langsung rata-rata pengeluaran per kapita.

\begin{tabular}{cccccc}
\hline Variabel Penyerta & $\begin{array}{c}\text { Pearson } \\
\text { Correlation }\end{array}$ & Sig. & Variabel Penyerta & $\begin{array}{c}\text { Pearson } \\
\text { Correlation }\end{array}$ & Sig. \\
\hline P_PLN & 0,293 & 0,000 & P_KUR & $-0,105$ & 0,007 \\
P_APOTEK & 0,504 & 0,000 & P_SD & $-0,133$ & 0,001 \\
P_POSYANDU & 0,189 & 0,000 & P_SMA & 0,112 & 0,004 \\
P_BPJS & $-0,193$ & 0,000 & P_PT & 0,349 & 0,000 \\
P_BTS & 0,287 & 0,000 & P_FASKES & 0,251 & 0,000 \\
P_KUD & $-0,103$ & 0,008 & P_NAKES & 0,330 & 0,000 \\
P_KOPERASI & 0,162 & 0,000 & & & \\
\hline
\end{tabular}

Sumber: BPS (2019), diolah

Tabel 1 merupakan hasil pengujian korelasi masing-masing variabel penyerta dengan hasil estimasi langsung rata-rata pengeluaran per kapita. Hasil tersebut menunjukan sebanyak 13 variabel memiliki korelasi dengan hasil estimasi langsung rata-rata pengeluaran per kapita yang ditandai dengan nilai signifikansi variabel penyerta yang lebih kecil dari $\alpha(0,05)$. Selanjutnya, variabel penyerta terpilih akan dilakukan deteksi multikolinearitas. Pendeteksian multikolinearitas ini dengan menghitung nilai VIF (Variance Inflation Factor) pada setiap variabel penyerta dan diperoleh nilai VIF sebagai berikut: 
Tabel 2. Variance Inflation Factor.

\begin{tabular}{lclc}
\hline \multicolumn{1}{c}{ Variabel Penyerta } & VIF & & Variabel Penyerta \\
\hline P_PLN & 5,330 & P_KUR & VIF \\
P_APOTEK & 4,673 & P_SD & 1,540 \\
P_POSYANDU & 3,155 & P_SMA & 5,044 \\
P_BPIS & 1,675 & P_PT & 5,750 \\
P_BTS & 2,429 & P_NAKES & 1,970 \\
P_KUD & 1,284 & P_FASKES & 3,558 \\
P_KOPERASI & 1,506 & & 1,557 \\
\hline
\end{tabular}

Sumber: BPS (2019), diolah

Hasil pendeteksian multikolinearitas dapat dilihat pada Tabel 2, diketahui bahwa seluruh variabel penyerta terpilih tidak terjadi pelanggaran multikolinearitas. Hal ini dikarenakan nilai VIF masing-masing variabel tidak lebih dari 10. Sehingga, dapat dinyatakan bahwa seluruh variabel terpilih tidak memiliki korelasi antar variabel.

\section{Permodelan EBLUP Fay-Herriot}

Tahap selanjutnya ialah melakukan estimasi tidak langsung menggunakan small area estimation menggunakan Model Empirical Best Linear Unbiased Prediction Fay-Herriot (EBLUP FH). Model ini hanya menggunakan variabel penyerta yang berasal dari sensus atau variabel yang tidak mengandung error. Jadi, sebanyak 13 variabel terpilih yang berasal dari data podes akan menjadi variabel penyerta pada Model EBLUP FH. Berikut hasil estimasi koefisien regresi beserta nilai koefisien keragaman acak $v_{i}\left(\hat{\sigma}_{v}^{2}\right)$ Model EBLUP FH disajikan pada Tabel 3 .

Tabel 3. Estimasi koefisien regresi dan koefisien dari keragaman acak Model EBLUP FH.

\begin{tabular}{ccc}
\hline Variabel & $\widehat{\boldsymbol{\beta}}_{\boldsymbol{i}}$ & P-value \\
\hline Intersep & 911095,847 & 0,000 \\
P_PLN & 8,908 & 0,000 \\
P_APOTEK & 14689,898 & 0,000 \\
P_POSYANDU & $-344,714$ & 0,511 \\
P_BPJS & $-3,363$ & 0,004 \\
P_BTS & 324,515 & 0,880 \\
P_KUD & $-6905,998$ & 0,397 \\
P_KOPERASI & 563,429 & 0,592 \\
P_KUR & 2460,496 & 0,123 \\
P_SD & $-5762,002$ & 0,000 \\
P_SMA & 3446,629 & 0,136 \\
P_PT & 22941,227 & 0,003 \\
P_NAKES & 456,629 & 0,678 \\
P_FASKES & 1782,020 & 0,555 \\
乔 & 52058005401,000 & - \\
\hline
\end{tabular}

Sumber: BPS (2019), diolah

Berdasarkan Tabel 3 diperoleh hasil bahwa lima variabel P_PLN, P_APOTEK, P_BPJS, P_SD, dan P_PT berpengaruh signifikan terhadap rata-rata pengeluaran per kapita di Jawa Timur. Variabel tersebut berpengaruh signifikan dikarenakan nilai $p$-value setiap variabel lebih kecil dibanding nilai $\alpha(5 \%)$. Adapun nilai keragaman acak $v_{i}$ sebesar $\hat{\sigma}_{v}^{2}=52058005401$. Hasil estimasi langsung dan tidak langsung rata-rata pengeluaran per kapita di Jawa Timur level kecamatan dapat dilihat pada Tabel 4.

Tabel 4. Statistik deskriptif hasil estimasi langsung dan EBLUP FH rata-rata pengeluaran per kapita Provinsi Jawa Timur 2019.

\begin{tabular}{ccc}
\hline Statistik & Estimasi Langsung (Rupiah) & EBLUP FH (Rupiah) \\
\hline Mean & 1.008 .624 & 957.319 \\
Standar Deviasi & 522.762 & 306.980 \\
Minimum & 375.140 & 381.415 \\
Median & 903.083 & 898.055 \\
Maksimum & 9.072 .423 & 2.361 .136 \\
Jangkauan & 8.697 .283 & 1.979 .721 \\
\hline
\end{tabular}

Sumber: BPS (2019), diolah 
Estimasi langsung yang diperoleh dari BPS menghasilkan data rata-rata pengeluaran per kapita level kecamatan di Jawa Timur. Estimasi langsung yang diperoleh hanya pada wilayah yang terdapat sampel rumah tangga. Pada data yang diperoleh, sebanyak 655 wilayah kecamatan dari 666 kecamatan di Provinsi Jawa Timur memiliki sampel rumah tangga dan 11 wilayah kecamatan lainya tidak tercakup sampel. Oleh karena itu, penelitian ini hanya menggunakan 655 kecamatan tersampel sebagai data estimasi langsung dan 11 kecamatan tidak tersampel akan diestimasi dengan menambahkan informasi cluster pada analisis selanjutnya.

Tabel 4 merupakan statistik deskriptif hasil estimasi langsung dan EBLUP FH. Hasil estimasi langsung rata-rata pengeluaran per kapita di Provinsi Jawa Timur memiliki rata-rata sebesar Rp 1.008.624, sedangkan pada Model EBLUP FH sebesar Rp 957.319. Hasil tersebut memberikan informasi bahwa rata-rata hasil estimasi dari kedua model tidak jauh berbeda. Namun jika ditinjau dari standar deviasinya, estimasi langsung memiliki nilai standar deviasi sebesar Rp 522.762, sedangkan Model EBLUP FH sebesar Rp 306.980 yang berarti bahwa keberagaman data hasil estimasi langsung cenderung lebih besar dibanding hasil estimasi pada metode SAE.

Selanjutnya nilai maksimum hasil estimasi pada kedua estimator dimiliki oleh wilayah kecamatan yang berbeda. Pada estimasi langsung, Kecamatan Wiyung di Kota Surabaya memiliki rata-rata pengeluaran per kapita tertinggi daripada wilayah lain dengan nilai sebesar Rp 9.072.423. Sedangkan pada model EBLUP FH, Kecamatan Gayungan yang berada di Kota Surabaya memiliki rata-rata pengeluaran per kapita tertinggi dengan nilai $\mathrm{Rp}$ 2.361.136. Berbeda dengan nilai maksimum, nilai minimum estimasi rata-rata pengeluaran per kapita pada kedua estimator dimiliki oleh kecamatan yang sama yaitu Kecamatan Tanjungbumi di Kabupaten Bangkalan. Nilai minimum hasil estimasi langsung sebesar Rp 375.140 dan pada Model EBLUP FH sebesar Rp 381.415. Dari informasi nilai minimum dan maksimum, diperoleh nilai jangkauan hasil estimasi masing masing model dimana estimasi secara langsung menghasilkan jangkauan data lebih besar dibanding model EBLUP FH.

\section{Perbandingan Mean Square Error dan Relative Root Mean Square Error}

Penentuan metode terbaik dapat dilakukan dengan membandingkan nilai MSE dan RRMSE yang dihasilkan dari masing-masing estimator. Metode terbaik nantinya dapat memberikan hasil pendugaan ratarata pengeluaran per kapita yang paling presisi. Oleh karena itu, perbandingan antar metode diperlukan untuk mendapatkan hasil estimasi yang paling mendekati dengan nilai populasinya. Adapun perbandingan metode estimasi yang akan dilakukan adalah estimasi langsung dengan metode SAE Model EBLUP FH. Perbandingan ini didasarkan pada nilai Relative Root Mean Square Error (RRMSE). Metode terbaik akan dipilih apabila metode tersebut memiliki nilai RRMSE yang paling kecil di setiap kecamatan. Berikut tabel ringkasan MSE kedua metode estimasi.

Tabel 5. Ringkasan Mean Square Error estimasi langsung dan EBLUP FH

\begin{tabular}{ccc}
\hline Statistik & Estimasi Langsung & EBLUP FH \\
\hline Rata-rata & 80.966 .826 .456 & 9.750 .358 .022 \\
Minimum & $3,368 \times 10^{-24}$ & $3,368 \times 10^{-24}$ \\
Median & 7.035 .272 .774 & 6.222 .173 .377 \\
Maksimum & 35.361 .620 .442 .441 & 54.006 .129 .595 \\
\hline
\end{tabular}

Sumber: BPS (2019), diolah

Berdasarkan Tabel 5, dapat diketahui nilai MSE di kedua metode estimasi. Nilai MSE tersebut selanjutnya digunakan untuk mencari nilai RRMSE. Hasil RRMSE dapat ditunjukan dengan Gambar 1 dan Gambar 2. Boxplot yang terdapat pada Gambar 1 menunjukan perbedaan hasil nilai RRMSE di kedua estimator. Terlihat bahwa nilai RRMSE dari estimasi langsung memiliki beberapa nilai yang tergolong tinggi, ditunjukan dengan beberapa data yang memiliki nilai RRMSE lebih besar dari 25 persen. Hal ini dapat dikatakan bahwa estimasi langsung memiliki presisi yang rendah atau dinilai kurang akurat dalam mengestimasi variabel respon. Jika dibandingkan dengan metode SAE, RRMSE EBLUP FH memiliki rentang nilai yang lebih kecil dibanding estimasi langsungnya. Hal ini membuktikan bahwa penggunaan Model EBLUP FH dapat menurunkan nilai RRMSE dari estimasi langsung. 


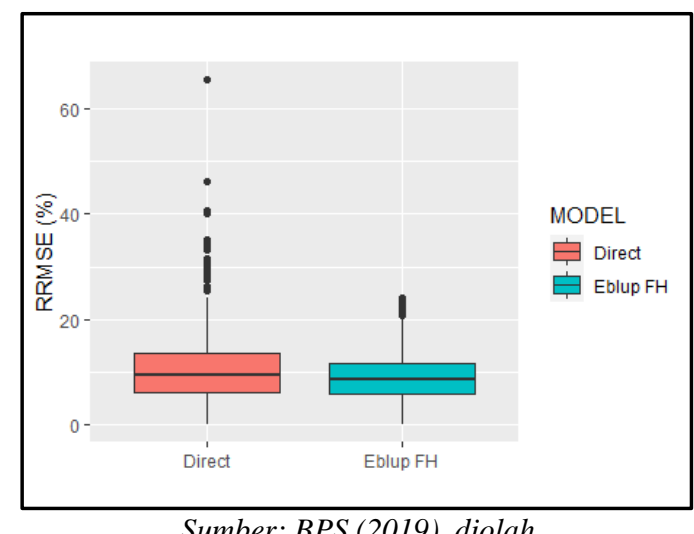

Gambar 1. Boxplot Relative Root Mean Square Error estimasi langsung dan Model EBLUP FH.

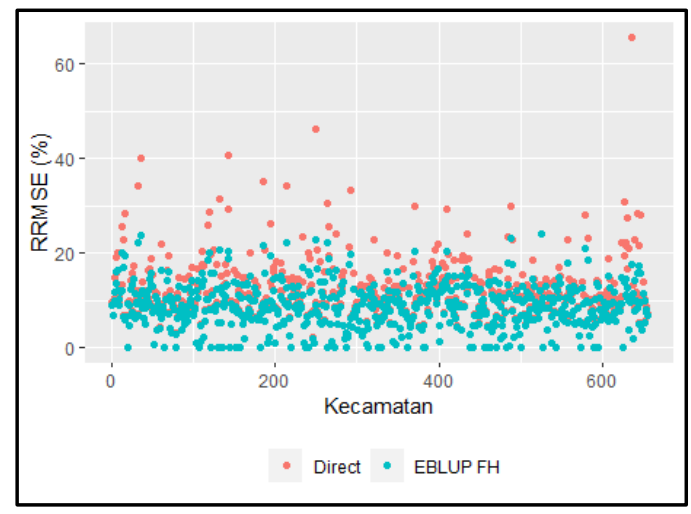

Sumber: BPS (2019), diolah

Gambar 2. Perbandingan grafik Relative Root Mean Square Error estimasi langsung dan Model EBLUP FH.

Selanjutnya perbandingan nilai RRMSE yang dihasilkan dari kedua estimator menggunakan grafik pada masing-masing kecamatan dapat dilihat melalui Gambar 2. Grafik tersebut memberikan informasi bahwa nilai RRMSE antar kecamatan pada estimasi langsung mampu diperbaiki oleh Model EBLUP FH dimana RRMSE Model EBLUP FH memiliki nilai yang lebih kecil dibanding estimasi langsungnya. Hal ini memberikan bahwa Model EBLUP FH merupakan estimator tebaik dalam mengestimasi rata-rata pengeluaran per kapita level kecamatan di Provinsi Jawa Timur tahun 2019.

\section{Estimasi Non-Sample Area}

Estimasi langsung hanya dapat dilakukan pada wilayah yang memiliki sampel rumah tangga didalamnya. Apabila suatu wilayah tidak memiliki sampel, maka wilayah tersebut tidak dapat diestimasi. Adanya metode SAE dengan tambahan informasi cluster dapat mengatasi wilayah-wilayah yang tidak tercakup sampel (nonsample area). Pada penelitian ini sebanyak 11 wilayah kecamatan yang tidak tercakup sampel akan dilakukan estimasi berdasarkan informasi cluster yang terbentuk. Cluster yang terbentuk sebanyak empat cluster. Hasil estimasi Model EBLUP FH beserta kelompok cluster pada kecamatan non-sample pada Tabel 6.

Tabel 6. Hasil Estimasi Rata-Rata Pengeluaran per Kapita Non-Sample Area

\begin{tabular}{ccccc}
\hline $\begin{array}{c}\text { Kode } \\
\text { Kecamatan }\end{array}$ & Kecamatan & KAPITA (Rupiah) & Cluster & RRMSE EBLUP FH Non-Sample \\
\hline 3505180 & Sanankulon & 831.877 & 3 & 12,867 \\
3507200 & Wonosari & 879.954 & 4 & 22,793 \\
3511151 & Ijen & 886.604 & 4 & 22,625 \\
3513010 & Sukapura & 852.320 & 4 & 23,532 \\
3517170 & Kudu & 984.851 & 4 & 20,378 \\
3518160 & Wilangan & 828.902 & 4 & 24,197 \\
3522040 & Ngambon & 886.487 & 4 & 22,626 \\
3522241 & Kedewan & 878.820 & 4 & 22,825 \\
3525170 & Sangkapura & 801.796 & 3 & 13,354 \\
3529071 & Batuan & 1.008 .870 & 4 & 19,887 \\
3578270 & Asemrowo & 879.534 & 4 & 22,808 \\
\hline
\end{tabular}


Berdasarkan Tabel 6, diperoleh hasil estimasi pada area yang tidak tercakup sampel. Sehingga, informasi tersebut dapat digunakan untuk melengkapi kecamatan yang tidak terestimasi pada Model EBLUP FH. Hasil ringkasan estimasi EBLUP FH setelah dilakukan penggabungan dengan non-sample area dapat dilihat melalui tabel berikut:

Tabel 7. Statistik Deskriptif Hasil Estimasi Rata-Rata Pengeluaran per Kapita Model EBLUP FH dengan Tambahan Informasi Cluster

\begin{tabular}{cc}
\hline Statistik & Nilai (Rupiah) \\
\hline $\mathrm{N}$ & 666 Kecamatan \\
Mean & 956.102 \\
Standar Deviasi & 304.444 \\
Minimum & 381.415 \\
Median & 893.500 \\
Maksimum & 2.361 .136 \\
Jangkauan & 1.979 .721 \\
\hline
\end{tabular}

Sumber: BPS (2019), diolah

Secara rata-rata, hasil estimasi rata-rata pengeluaran per kapita menggunakan Model EBLUP FH dengan tambahan infomasi cluster memiliki nilai sebesar Rp 956.102. Standar deviasi pada model ini memiliki nilai sebesar Rp 304.444. Selanjutnya, hasil estimasi tersebut memiliki nilai minimum sebesar Rp 381.415 dan nilai maksimum sebesar Rp 2.361.136 sehingga jangkauan data yang dihasilkan sebesar Rp 1.979.721. Dengan adanya nilai RRMSE yang tidak lebih dari 25 persen, maka terindikasi EBLUP FH clustering memiliki presisi yang baik dalam mengestimasi rata-rata pengeluaran per kapita pada wilayah non-sample.

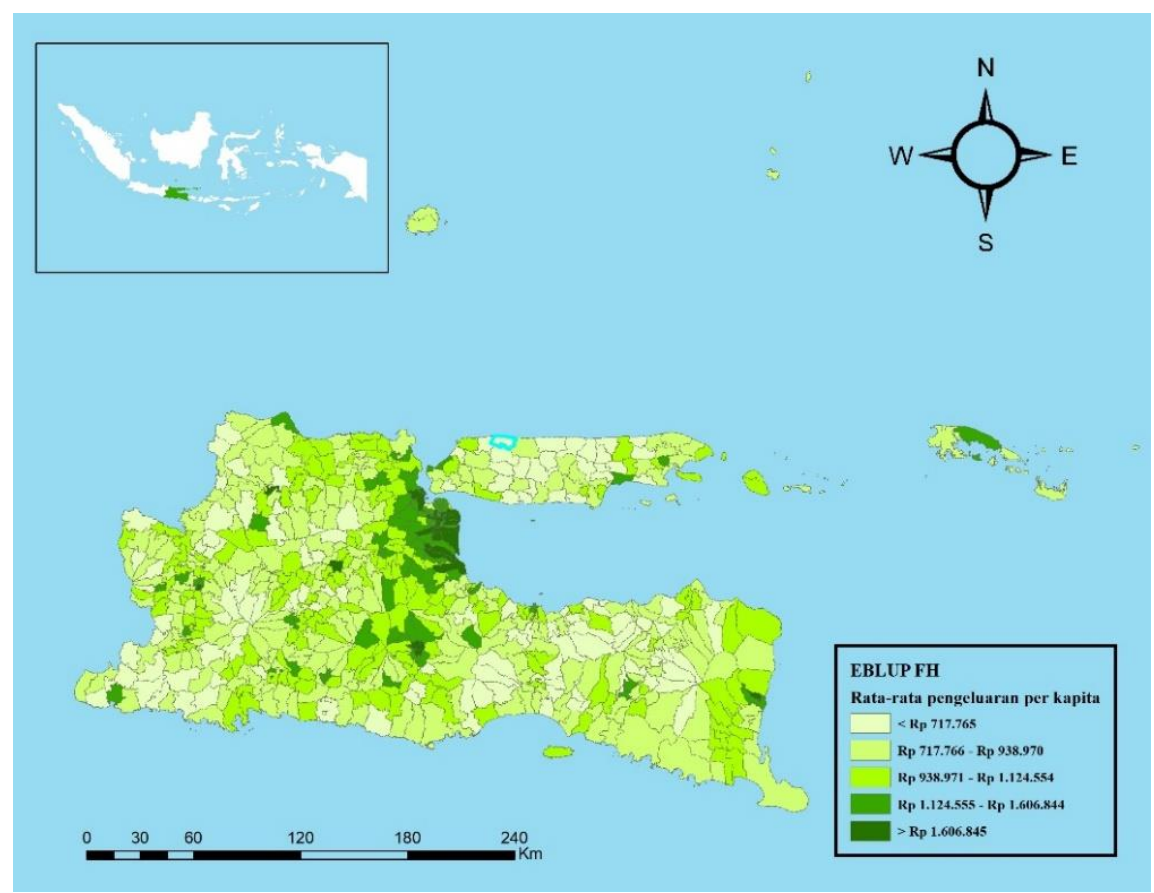

Gambar 3. Hasil Estimasi EBLUP FH pada Seluruh Kecamatan

Hasil estimasi pada non-sample area selanjutnya dapat dipetakan. Pemetaan ini menggunakan hasil estimasi dari EBLUP FH dikarenakan model tersebut adalah model yang digunakan untuk mendapatkan estimasi rata-rata pengeluaran per kapita pada non-sample area. Dasar pengklasifikasian pemetaan rata-rata pengeluaran per kapita level kecamatan menggunakan Natural Breaks dimana pengklasifikasian ini menggunakan algoritma untuk meminimalkan perbedaan data dalam kategori dan memaksimalkan perbedaan data antar kategori (Chang, 2018). Hasil estimasi EBLUP FH pada pada seluruh area kecamatan dapat disajikan melalui Gambar 3. Perbedaan warna pada peta sebaran menunjukan perbedaan klasifikasi hasil estimasi. Semakin berwarna hijau gelap suatu kecamatan, maka semakin tinggi rata-rata pengeluaran per kapita kecamatan tersebut. Berdasarkan data hasil pendugaan rata-rata pengeluaran per kapita, kecamatan dengan rata-rata pengeluaran per kapita tertinggi adalah Kecamatan Gayungan yang berada pada Kota Surabaya dengan hasil estimasi Rp 2.361.136, sedangkan kecamatan dengan rata-rata pengeluaran per kapita terendah 
dimiliki oleh Kecamatan Tanjungbumi yang berada pada Kabupaten Bangkalan dengan hasil estimasi sebesar Rp 381.415.

\section{KESIMPULAN}

Berdasarkan hasil penelitian, permodelan EBLUP FH menghasilkan nilai rata-rata pengeluaran per kapita tertinggi sebesar Rp 2.361.136 tepatnya berada pada Kecamatan Gayungan di Kota Surabaya. Sedangkan ratarata pengeluaran per kapita terendah sebesar Rp 381.415 yang berada pada Kecamatan Tanjungbumi di Kabupaten Bangkalan. Berdasarkan hasil penelitian juga dapat disimpulkan bahwa metode SAE dengan Model EBLUP FH lebih presisi dibanding estimasi langsung dalam mengestimasi rata-rata pengeluaran per kapita level kecamatan di Jawa Timur tahun 2019. Hal tersebut ditunjukan dengan nilai perbandingan RRMSE di setiap kecamatan, dimana estimasi tidak langsung Model EBLUP FH memiliki nilai RRMSE yang lebih kecil dibanding estimasi langsung. Selanjutnya penambahan informasi cluster cukup efektif dalam mengestimasi non-sample area yang ditandai dengan nilai RRMSE pada masing-masing wilayah tidak lebih dari 25 persen. Saran yang diajukan Bagi pemerintah dapat memprioritaskan wilayah yang memiliki hasil estimasi rata-rata pengeluaran per kapita yang tergolong tinggi untuk mendongkrak perekonomian regional seperti Kecamatan Gayungan di Kota Surabaya. Selain itu, pemerintah juga perlu meningkatkan program pengentasan kemiskinan pada wilayah yang memiliki hasil estimasi rata-rata pengeluaran per kapita yang tergolong rendah seperti Kecamatan Tanjungbumi di Kabupaten Bangkalan.

\section{DAFTAR PUSTAKA}

Amaliana, L., \& Lusiana, E. D. (2017, July). Penerapan Metode Empirical Best Linear Unbiased Prediction (EBLUP) pada Model Fay-Herriot Small Area Estimation (SAE). In Prosiding SI MaNIs (Seminar Nasional Integrasi Matematika dan Nilai-Nilai Islami) (Vol. 1, No. 1, pp. 312-318).

Annisa R., Kurnia A., Indahwati. (2014). Cluster Information of Non-Sampled Areain Small Area Estimation. IOSR Journal of Mathematics 10(1): 15-19.

Bappenas. (2014). Rencana Pembangunan Jangka Menengah Nasional (RPJMN) 2015-2019. Jakarta: Bappenas

Bappenas. (2017). Sustainable Development Goals (SDGs). Jakarta: Bappenas.

BPS. (2009-2019). Berita Resmi Statistik: Profil Kemiskinan di Indonesia. Jakarta: Badan Pusat Statistik.

Chang, K. T. (2018). Introduction to geographic information systems (Vol. 9). New York: McGraw-Hill Education.

Haris, Faisal. (2019). Kajian MSE Area Tidak Tersampel pada Small Area Estimation. [Skripsi]. Jakarta: Politeknik Statistika STIS.

Kusuma, W. (2017). Small Area Estimation Terhadap Pengeluaran per Kapita Di Kabupaten Banyuwangi Dengan Metode Hierarchical Bayes Dan Empirical Bayes (Doctoral dissertation, Institut Teknologi Sepuluh Nopember).

Rao JNK. (2003). Small area estimation. London: Wiley.

World Bank. (2000). World Development Report: Attacking Poverty. Washington: Oxford University Press. 